\title{
Grain Quality of Maize Cultivar Giza 168 as Affected by Levels of Irrigation, Sowing Date, Plant Density and Macronutrients
}

\author{
Ola E. Zakaria ${ }^{1}$, Mohamed M. El-Rouby ${ }^{2}$, Mona M. Hemied ${ }^{2}$
}

\begin{abstract}
Two field experiments were conducted at Agricultural Research Station, Faculty of Agriculture, Alexandria University, Egypt, through summer seasons of 2015 and 2016 to investigate the effect of six main factors (irrigation, potassium, phosphorus and nitrogen fertilization, sewing date and plant density) on some quality parameters i. e.(oil, starch, total sugar content and oil yield / ha) of maize cultivar Giza 168. A five- levels- six- factor Rotatable Central Composite Design (RCCD) was adopted in the present study. The results indicated that early sowing in May increased starch and oil contents of maize grains, while increasing plant density above 60,000 plants /ha led to decrease in starch content. Oil yield was positively increased with increasing plant density due to increase in grain yield. Nitrogen and potassium fertilization increased oil and starch contents of the grains up to $258 \mathrm{~kg} \mathrm{~N} / \mathrm{ha}$ and $136 \mathrm{~kg} \mathrm{~K} \mathrm{O} / \mathrm{ha}$, respectively. Total sugars were positively influenced by increasing levels of all studied factors, except phosphorus where it showed a negative relationship as $P$ level was increased above $50 \mathrm{~kg}$ $\mathrm{P}_{2} \mathrm{O}_{5}$ / ha.
\end{abstract}

Key Words: Maize, grin quality, irrigation, plant density, macronutrients, sowing date.

\section{INTRODUCTION}

In Egypt, the agricultural development is considered the Maize is one of the most important cereal crops world wide, and the most widely grown summer crop in Egypt. It can be used as human food and animal and poultry feed. It is a very good source of starch (60$80 \%$ ), oil (4-6\%) and sugars, hence maize is used as raw material in many industries (starch products, oil and sugars). Productivity and quality parameters of maize as in other field crops, is influenced by several factors, however agricultural inputs and practices are determinate for proper growth, grain quality traits, i.e. (oil, starch and sugar contents) and grain yield. These include choice of the suitable sowing date to provide the plants with ideal environmental conditions for growth, transition from vegetative to reproductive stage and grain filling and avoid biotic stresses (diseases and insects) at critical growth stages. Seeding at the appropriate plant density will increase grain quality parameters and grain yield through decreasing intracrop competition and realization of optimum or near to optimum stand at harvest. Abhishek and Basavanneppa (2020) found that high grain content of oil, starch and sugars were obtained with low plant density.

Water plays a vital role in germination, growth, nutrients and photosynthates translocation, facilitation of biochemical processes in the plant and governs pollination and fertilization, hence determination of irrigation requirements is a necessity to avoid that drastic effect of drought or excessive irrigation on plant growth, productivity and grain quality characters. Ali $e t$ al. (2013) and Kaplan et al. (2017) found that oil grain content increased with availability of irrigation water. Moreover, Ibrahim and Kandil (2007) reported that grain starch content was increased with availability of irrigation Water. On the other hand, Ali et al. (2013) and Liu et al. (2013) found that grain sugar content was decreased with drought.

Sowing date is an important factor in determining the grain quality as reported by several investigators. Kara et al. (2012) and Koca and Canavar (2014) found that by delaying sowing date of maize ,the grain oil and sugar content decreased, whereas, the grain starch content was increased.

The nutritional status of the plant has a substantial effect on its growth, productivity and grain quality traits. The important roles played by the three macroelements, i.e., nitrogen, phosphorus and potassium in growth, biochemical processes, yield and quality of maize are well documented, however rates of application should be determined to avoid deficient or excess application. Bukhsh et al. (2009) found improvement in grain oil and starch contents with increasing K level. Ibrahim and Kindil (2007) found increase in grain oil and starch content with increasing $\mathrm{N}$ and $\mathrm{P}$ rates.

Due to the large number of factors included in the present study, a central composite design with half replication was employed to determine the main effects

DOI: 10.21608/ASEJAIQJSAE.2020.127606

${ }^{1}$ PH. Graduate student, Crop Science Dept., Faculty of Agriculture, Alexandria University.

${ }^{2}$ Department of Crop Science, Faculty of Agriculture,

Alexandria University, Alexandria, Egypt.

* Corresponding author's email: mona.mohamed@alexu.edu.eg

Received November 4, 2020, Accepted, December 3, 2020. 
of studied factors and their linear interaction. The purpose of employment of that design was to decrease the number of experimental units as indicated by Cochran and Cox (1957). To our knowledge, this is the first time such design was employed in field experiments.

The main objective of the present study was to investigate the effect of six main factors ( irrigation, fertilization with various macro- elements, i.e. potassium, phosphorus and nitrogen, sowing date and plant density) on grain quality characteristics (oil, starch and total sugars content) of maize cultivar Giza168.

\section{MATERIALS AND METHODS}

The present study was carried out at the Agricultural Research Station, Faculty of Agriculture, Alexandria University, Egypt, during the two summer seasons of 2015 and 2016. The cultivar used in both seasons was single hybrid Giza 168 (Giza $658 \times$ Giza 639).A fivelevels-six-factors rotatable central composite design (Box and Wilson, 1951) was adopted in the present study. The total number of experimental units used was 56 including 32 factorial points, 12 central points and 12 star points. Experimental unit area was $28 \mathrm{~m}^{2}$ (10 ridges each of width $0.7 \mathrm{~m}$ and $4 \mathrm{~m}$ length). Before sowing, soil samples were taken from the experimental site $(0-$ $35 \mathrm{~cm}$ from soil surface). The preceding crop was Egyptian clover in both seasons. The chemical and physical properties of soil (Black et al., 1965 and Page et al., 1982) are presented in Table (1).

Sowing was on one side of the ridge in hills (the distance between hills for experimental unit varied according to the levels of plant density) and the plants were thinned to one plant/ hill after 24 days from sowing. Factors levels and application are shown in Table (2).
Surface irrigation was applied through a pipe system with a water meter attached to it to measure amount of water applied. Wide borders and deep furrows were used to isolate plots in order to eliminate the carry-over resulting from ground water level for different irrigation levels. Phosphorus was applied in the form of calcium monophosphate $\left(\begin{array}{lll}15.5 \% & \mathrm{P}_{2} \mathrm{O}_{5}\end{array}\right)$, while Nitrogen was applied in the form of urea $(46.5 \% \mathrm{~N})$. Potassium was applied in the form of potassium sulphate $\left(48 \% \mathrm{~K}_{2} \mathrm{O}\right)$. Experimental units were kept weed-free through hand hoeing at early stages and hand pulling at later stages to eliminate the weeds effect.

Grain oil content $(\%)$ was determined according to A.O.A.C. (1990). Knowing the composition of the grain, the theoretical oil yield was calculated as follow:

Oil yield $\left(\mathrm{kg} \mathrm{ha}^{-1}\right)=[$ Oil content $(\%) *$ Grain yield $(\mathrm{kg}$ $\left.\left.\mathrm{ha}^{-1}\right)\right] / 100$.

Phenol sulphuric acid method proposed by Malik and Singh (1980) was used to determine the starch content in grains, while total sugar content was determined according to Comeroglu (1992).

The error of the two years for studied characters was homogenous, as determined by test of homogeneity of error (Hartley, 1950), hence the data were combined over the two years.

Statistical analysis was carried out according to Peterson (1985), using the statistical software package "STATISTICA 7.0", (StatsSoft, 2012).

Response surface and contour diagrams for significant Linear $\times$ Linear interactions were performed by STATISTICA 7.0 (StatSoft, 2012), while linear and quadratic responses of main effects were performed by Curve Expert, ver. 1.34 (Hyams, 2005).

Table 1. Soil physical and chemical properties as an average of the two seasons

\begin{tabular}{|c|c|c|c|}
\hline & Values & & Values \\
\hline Physical properties & & Nutritional properties & \\
\hline Sand $\%$ & 62.5 & Av. N (\%) & 0.01 \\
\hline Silt $\%$ & 20.0 & Av.P (ppm) & 9.60 \\
\hline Clay $\%$ & 17.5 & Av. K (meq/ L) & 0.84 \\
\hline Texture & Sand loam & Organic matter $(\%)$ & 0.52 \\
\hline \multicolumn{4}{|l|}{ Chemical properties } \\
\hline $\mathrm{pH}$ & 8.36 & $\mathrm{Cl}^{-}(\mathrm{meq} / \mathrm{L})$ & 15.00 \\
\hline $\mathrm{EC}(\mathrm{dS} / \mathrm{m})$ & 2.23 & $\mathrm{CO}_{3}^{-2}(\mathrm{meq} / \mathrm{L})$ & 2.40 \\
\hline $\mathrm{Ca}^{+2}$ (meq/ L) & 7.50 & $\mathrm{HCO}_{3}^{-}(\mathrm{meq} / \mathrm{L})$ & 4.00 \\
\hline $\mathrm{Mg}^{+2}($ meq/L) & 4.00 & $\mathrm{CaCO}_{3}(\%)$ & 9.86 \\
\hline $\mathrm{Na}^{+}(\mathrm{meq} / \mathrm{L})$ & 20.21 & SAR & 5.96 \\
\hline
\end{tabular}


Table 2. Coded and actual levels of studied factors in central composite design.

\begin{tabular}{|c|c|c|c|c|c|c|c|c|}
\hline Factors & Cod & d level & Units & $\begin{array}{c}-S \\
-\alpha(-2.374) \\
\end{array}$ & $\begin{array}{l}-F \\
(-1)\end{array}$ & $\begin{array}{c}\text { Central point } \\
(0)\end{array}$ & $\begin{array}{c}+\mathbf{F} \\
(+1)\end{array}$ & $\begin{array}{c}+\mathrm{S} \\
+\alpha(2.374) \\
\end{array}$ \\
\hline Irrigation levels ${ }^{(1)}$ & (I) & $\left(\mathrm{X}_{1}\right)$ & $\mathrm{m}^{3} / \mathrm{ha}$ & 4879 & 6388 & 7259 & 8130 & 9639 \\
\hline Potassium levels & $(\mathrm{K})$ & $\left(\mathrm{X}_{2}\right)$ & $\mathrm{kg} / \mathrm{ha}$ & 0.0 & 41.4 & 71.4 & 101.4 & 142.8 \\
\hline Phosphorus levels & (P) & $\left(\mathrm{X}_{3}\right)$ & $\mathrm{kg} / \mathrm{ha}$ & 0.0 & 34.5 & 59.5 & 84.5 & 119 \\
\hline Nitrogen levels ${ }^{(4)}$ & $(\mathrm{N})$ & $\left(\mathrm{X}_{4}\right)$ & $\mathrm{kg} / \mathrm{ha}$ & 0.0 & 110.9 & 190.4 & 270.4 & 380.8 \\
\hline Sowing date & (SD) & $\left(\mathrm{X}_{5}\right)$ & days & $15 / 6$ & $3 / 6$ & $24 / 5$ & $13 / 5$ & $1 / 5$ \\
\hline Plant density/ ha & (PD) & $\left(\mathrm{X}_{6}\right)$ & plants/ha & 38080 & 54621 & 66640 & 78659 & 95200 \\
\hline
\end{tabular}

S: Star points.

F: Factorial points.

,-+ : minimum and maximum levels, respectively.

(1) All levels were applied in nine irrigations (at 12 days interval) as surface irrigation. The amount for each irrigation varied with level of irrigation and plant growth stage. Irrigation was terminated ten days before harvesting.

(2) All levels were added in split equal doses just before the fourth and fifth irrigations.

(3) Added at land preparation.

(4) All levels were added in split equal doses at 24 days from sowing and at the following irrigation, except for 380.8 $\mathrm{kgN} / \mathrm{ha}$ which was added in three doses, i.e., $142.8,142.8$ and $95.2 \mathrm{kgN} / \mathrm{ha}$, at 24 days from sowing and the two subsequent irrigations, respectively.

\section{RESULTS AND DISCUSSION}

\section{1) Grain oil content (\%):}

The regression coefficient values (Table 3) indicated that grain oil content was significantly and negatively affected by linear component for irrigation levels ($\left.0.0009^{*}\right)$, positively $(0.0001 *)$ affected by quadratic component of plant density and positively $\left(0.0001^{*}\right)$ affected by linear interaction $\left(\mathrm{K}^{*} \mathrm{~N}\right)$.Hence, the regression equation that illustrated the relationship between grain oil content and significant components will be:

$\mathrm{Y}=13.92-0.0009 \mathrm{X}_{1}+0.0001 \mathrm{X}_{6}^{2}+0.0001 \mathrm{X}_{2} \mathrm{X}_{4}$, with a coefficient of determination $\left(\mathrm{R}^{2}\right)$ value of 0.57 .

The regression analysis on irrigation levels( fig. 1) showed that the grain oil content decreased linearly with increasing levels of irrigation with $\mathrm{R}^{2}=0.98$.

Increasing irrigation above optimal levels leads to depletion of nutrients from the soil through deep percolation, thus influencing its uptake by plants. Meanwhile, the availability of ample water increases grain starch content through increasing photosynthesis and translocation of photosynthates to the seed and that may lead to a decrease in oil content of grain. Similar findings were reported by Karasu et al. (2015). Moreover, (fig.2) present the quadratic relationship between grain oil content and plant density $\left(R^{2}=0.96\right)$, which indicated a decrease in oil content up to 66640.0 plant/ha then, that character increased with increasing plant density. The optimal plant density was 60241 plant /ha. Increasing plant density leads to more competition between plants for growth resources and hence decreases oil content of grain. However, further increase in plant density causes a decrease in grain size (Zakaria 2017) and an apparent increase in oil content. Abhishek and Basavanneppa (2020) reported that low plant density increased quality parameters of maize grain including oil content.

The effect of the linear interaction between the potassium and the nitrogen fertilization on grain oil content, was significant and positive $\left(\mathrm{R}^{2}=0.57\right)$. The response surface (fig.3) showed that grain oil content increased with increasing levels of the two factors together compared to the individual application of each factor.

The coefficient of variation for grain oil content was $4.0 \%$ indicating that variation in this character was small and depended mainly on the variation of factor levels, and their different interactions (table 3 ).

These findings were confirmed by the mean grain oil content (table 4) where the highest value $(7.5 \%)$ was obtained at the highest density of plants per hectare followed by high level of potassium and nitrogen fertilization( $\mathbf{F}_{\mathbf{1 1}} \mathbf{7 . 2 1 \%}$ ).

\section{2- Oil yield /ha}

The regression coefficient values revealed that oil yield /ha was significantly and positively affected by linear component of plant density $\left(0.000003^{*}\right)$ and negatively affected linear interaction $\left(\mathrm{I}^{*} \mathrm{~K}\right)\left(-0.000001^{*}\right)$ and $\left(-0.000023^{*}\right)$ for linear interaction $\mathrm{P}^{*} \mathrm{~N}$. Hence the regression equation that indicated the relationship between oil yield/ha and significant components will be: $\mathrm{Y}=-0.33+0.000003 \mathrm{X}_{6}-0.000001 \mathrm{X}_{1} \mathrm{X}_{2}-0.000023$

$\mathrm{X}_{3} \mathrm{X}_{4} \quad$ with $\mathrm{R}^{2}$ value of 0.52 
Data presented in (Fig. 4) showed that the oil yield was increased linearly by increasing plant density per hectar with $\mathrm{R}^{2}$ value of (0.69).

The effect of the linear interaction between the irrigation levels and potassium fertilization $(\mathrm{I} * \mathrm{k})$, on oil yield, was significant and negative. The response surface (fig.5), showed that the highest oil yield/ha was obtained with high level of potassium fertilization and low level of irrigation, while the lowest oil yield/ha was obtained with low levels of the two factors.

Moreover, the linear interaction between phosphorus and nitrogen fertilization levels showed significant and negative relationship with oil yield. The response surface (fig.6) revealed that oil yield increased with increasing the levels of one factor with intermediate levels of the other factor, while the combined application of both factors at lowest and highest levels gave lower values than application of highest levels of individual factors. The increase in oil yield/ha, could be attributed to the increase in grain yield with increasing plant density rather than increase in grain oil content as found previously. In addition, higher potassium levels at low irrigation level increased oil yield through improving oil content in grains. That maybe due to the role of $\mathrm{K}$ in enhancing translocation of photoassimilates to grains and increasing grain weight.

These findings are in agreement with those reported by Bukhsh et al. (2009). Increasing phosphorus levels increased oil content in grains and that is due to the function of $\mathrm{P}$ in oil synthesis in plants (Ayub et al., 2002 Fageria and Barbosafilho, 2007). Thus increasing $\mathrm{P}$ fertilization will increase oil yield. However, increasing $\mathrm{N}$ fertilization decreases oil content in grains due to the role of $\mathrm{N}$ in increasing protein and starch components of the grain. Hence, a balanced application of the two macronutrients is necessary for obtaining high grain oil content. However, increasing $\mathrm{N}$ fertilization level will increase oil yield through increasing grain yield (Ghassemi-Golezani et al., 2015).

The coefficient of variation for oil yield was 16.83 $\%$ (table 3) which indicate a considerable effect for grain yield on that character which is affected by factors not included in this study such as climatic conditions, weed population etc....

Means of oil yield (table 4) indicated that the highest value $(0.68 \mathrm{ton} / \mathrm{ha})$ was obtained at the highest plant density $\left(\mathrm{S}_{12}\right)$ followed by the high level of both $\mathrm{P}$ fertilization $\left(\mathbf{S}_{6}, 0.65\right.$ ton/ha) and $\mathrm{K}$ fertilization $\left(\mathbf{S}_{\mathbf{4}}\right.$, 0.61 ton/ha).

\section{3- Grain starch content (\%):}

The regression coefficient values (Table 3) indicated that the grain starch content was significantly and negatively affected by the linear component for irrigation levels $\left(-0.0103^{*}\right)$ and the interactions $\left(\mathrm{K}^{*} \mathrm{~N}\right)$, $(\mathrm{K} * \mathrm{SD}),(\mathrm{P} * \mathrm{~N}),(\mathrm{P} * \mathrm{SD})$ and $(\mathrm{SD} * \mathrm{PD})$. The quadratic component for potassium, phosphorus and nitrogen fertilization levels in addition to sowing date and plant density positively affected grain starch content $\left(0.0011^{*}\right.$, $0.0013^{*}, 0.0002^{*}, 1.38^{*}$ and $0.0001^{*}$, respectively). Also, the linear interactions $\left(\mathrm{I}^{*} \mathrm{~K}\right),\left(\mathrm{I}^{*} \mathrm{~N}\right),\left(\mathrm{I}^{*} \mathrm{PD}\right)$ and $(\mathrm{N} * \mathrm{PD})$ were positive $(0.0001,0.00011,0.0001$ and 0.0001 , respectively). Hence, the regression equation that illustrates the relationship between grain starch content and significant components will be:

$$
\begin{aligned}
\mathrm{Y}= & 46.72-0.0103 \mathrm{X}_{1}+0.0011 \mathrm{X}_{2}^{2}+0.0013 \mathrm{X}_{3}^{2}+0.0002 \\
& \mathrm{X}_{4}^{2}+1.3788 \mathrm{X}_{5}^{2}+0.0001 \mathrm{X}_{6}^{2}+0.0001 \mathrm{X}_{1} \mathrm{X}_{2}+ \\
& 0.0001 \mathrm{X}_{1} \mathrm{X}_{4}+0.0001 \mathrm{X}_{1} \mathrm{X}_{6}-0.0003 \mathrm{X}_{2} \mathrm{X}_{4}-0.0196 \\
& \mathrm{X}_{2} \mathrm{X}_{5}-0.0004 \mathrm{X}_{3} \mathrm{X}_{4}-0.0198 \mathrm{X}_{3} \mathrm{X}_{5}+0.0001 \mathrm{X}_{4} \mathrm{X}_{6}- \\
& 0.0001 \mathrm{X}_{5} \mathrm{X}_{6} .
\end{aligned}
$$

Since the significant interactions included all studied factors, the results of interaction will only be presented due to the interactive effects of studied factors in expression of the obtained results.

The effect of the interaction between the irrigation levels and potassium fertilization on grain starch content was significant and positive. The response surface (fig.7) revealed that the higher values for this trait were obtained when both factors were applied together highest levels. Moreover, the linear interaction between irrigation levels and the nitrogen fertilization levels was significant and positive. The response surface (Fig.8) showed that grain starch content increased with increasing levels of nitrogen fertilization with the low and intermediate level of irrigation, then decreased insignificantly with increasing water application levels. The irrigation levels * plant density (fig.9) interaction was significant and positive with grain starch content. The low level of both irrigation and plant density together gave high values for that character followed by the highest levels of both factors with insignificant difference between them.

The (PD*N) interaction (fig.14) indicated that high grain starch content was primarily affected by nitrogen content, where increasing $\mathrm{N}$ fertilization increased grain starch content. However, at higher plant densities, an apparent increase in starch content of grains was observed, especially at low $\mathrm{N}$ fertilization levels and that may be attributed to smaller size of grains as affected by higher number of plants and low nitrogen availability.

The $(\mathrm{N} * \mathrm{~K})$ and $(\mathrm{N} * \mathrm{P})$ interactions (fig.10 and 12) showed that increasing $\mathrm{N}$ fertilization gave higher starch content even at low levels of both K and P. On the other hand, at low $\mathrm{N}$ levels, high levels of both $\mathrm{K}$ and $\mathrm{P}$ are needed to obtain high grain starch content. 
The interaction of sowing date with $\mathrm{K}$ (fig.11), $\mathrm{P}$ (fig.13) and plant density (fig.15) revealed that early sowing (1- 13 May) resulted in high grain starch content with low levels of the other three factors. Delaying sowing to June required increasing the levels of $\mathrm{K}$ and $\mathrm{P}$ to increase grain starch content, while increasing plant density resulted in an apparent increase in that trait due to reduction in grain size (Zakaria 2017).

Table 3. Regression coefficients for oil percentage, oil yield, starch percentage and total sugar percentage as affected by the studied factors and their interactions

\begin{tabular}{|c|c|c|c|c|c|}
\hline & & $\begin{array}{c}\text { Oil } \\
(\%) \\
\beta \\
\end{array}$ & $\begin{array}{c}\text { Oil yield } \\
\text { (ton/ ha) } \\
\beta \\
\end{array}$ & $\begin{array}{c}\text { Starch } \\
(\%) \\
\beta \\
\end{array}$ & $\begin{array}{c}\text { Total } \\
\text { sugar }(\%) \\
\beta \\
\end{array}$ \\
\hline & $\beta 0$ & 13.9232 & -0.33 & $46.72 *$ & $6.181 *$ \\
\hline (1) I (L) & $\beta 1$ & $-0.0009^{*}$ & 0.000028 & $-0.0103 *$ & $0.275^{*}$ \\
\hline $\mathrm{I}(\mathrm{Q})$ & $\beta 11$ & 0.0000 & 0.000000 & 0.0000 & 0.028 \\
\hline (2) K (L) & $\beta 2$ & 0.0042 & 0.007034 & -0.5978 & 0.255 \\
\hline $\mathrm{K}(\mathrm{Q})$ & $\beta 22$ & -0.0001 & -0.000004 & $0.0011^{*}$ & $0.253^{*}$ \\
\hline (3) $P(L)$ & $\beta 3$ & 0.0017 & 0.004847 & -0.1443 & $-0.289 *$ \\
\hline $\mathrm{P}(\mathrm{Q})$ & $\beta 33$ & -0.0001 & 0.000009 & $0.0013 *$ & 0.173 \\
\hline (4) $\mathrm{N}$ (L) & $\beta 4$ & -0.0041 & 0.000364 & 0.1356 & -0.140 \\
\hline $\mathrm{N}(\mathrm{Q})$ & $\beta 44$ & 0.0000 & -0.000002 & $0.0002 *$ & $0.405^{*}$ \\
\hline (5) SD (L) & $\beta 5$ & 0.1308 & -0.123635 & 6.2483 & -0.014 \\
\hline $\mathrm{SD}(\mathrm{Q})$ & $\beta 55$ & 0.0109 & -0.018238 & $1.3788^{*}$ & $0.364 *$ \\
\hline (6) PD (L) & $\beta 6$ & -0.0001 & $0.000003 *$ & -0.0009 & -0.051 \\
\hline $\mathrm{PD}(\mathrm{Q})$ & $\beta 66$ & $0.0001 *$ & 0.000000 & $0.0001^{*}$ & $0.261^{*}$ \\
\hline $\mathrm{I} * \mathrm{~K} \quad(\mathrm{~L})$ & $\beta 12$ & 0.0000 & $-0.000001 *$ & $0.0001^{*}$ & -0.006 \\
\hline $\mathrm{I} * \mathrm{P}(\mathrm{L})$ & $\beta 13$ & 0.0000 & 0.000000 & 0.0000 & 0.078 \\
\hline $\mathrm{I} * \mathrm{~N}(\mathrm{~L})$ & $\beta 14$ & 0.0000 & 0.000000 & $0.0001 *$ & 0.038 \\
\hline $\mathrm{I} * \mathrm{SD}(\mathrm{L})$ & $\beta 15$ & 0.0000 & 0.000017 & -0.0001 & 0.098 \\
\hline $\mathrm{I} * \mathrm{PD}(\mathrm{L})$ & $\beta 16$ & 0.0000 & 0.000000 & $0.0001 *$ & -0.012 \\
\hline $\mathrm{K}^{*} \mathrm{P}(\mathrm{L})$ & $\beta 23$ & 0.0000 & 0.000000 & -0.0005 & -0.157 \\
\hline $\mathrm{K} * \mathrm{~N}(\mathrm{~L})$ & $\beta 24$ & $0.0001 *$ & 0.000004 & $-0.0003^{*}$ & 0.117 \\
\hline $\mathrm{K} * \mathrm{SD}(\mathrm{L})$ & $\beta 25$ & 0.0013 & -0.000615 & $-0.0196^{*}$ & -0.050 \\
\hline $\mathrm{K} * \mathrm{PD}(\mathrm{L})$ & $\beta 26$ & 0.0000 & 0.000000 & 0.0000 & -0.054 \\
\hline $\mathrm{P} * \mathrm{~N}(\mathrm{~L})$ & $\beta 34$ & 0.0000 & $-0.000023^{*}$ & $-0.0004^{*}$ & -0.233 \\
\hline $\mathrm{P} * \mathrm{SD}(\mathrm{L})$ & $\beta 35$ & -0.0002 & -0.000012 & $-0.0198 *$ & 0.029 \\
\hline $\mathrm{P} * \mathrm{PD}(\mathrm{L})$ & $\beta 36$ & 0.0000 & 0.000000 & 0.0000 & -0.216 \\
\hline $\mathrm{N} * \mathrm{SD}(\mathrm{L})$ & $\beta 45$ & 0.0005 & 0.000074 & 0.0034 & 0.220 \\
\hline $\mathrm{N} * \mathrm{PD}(\mathrm{L})$ & $\beta 46$ & 0.0000 & 0.000000 & $0.0001 *$ & 0.083 \\
\hline $\mathrm{SD} * \mathrm{PD}(\mathrm{L})$ & $\beta 56$ & 0.0000 & 0.000001 & $-0.0001^{*}$ & 0.151 \\
\hline $\mathrm{R}^{2}$ & & 0.57 & 0.52 & 0.61 & 0.69 \\
\hline C.V. (\%) & & 4.00 & 16.83 & 1.70 & 11.00 \\
\hline
\end{tabular}

* : Significant at 0.05 level of prpbability. 
Table 4. Means for oil percentage, oil yield, starch percentage and total sugar percentage as affected by studied factors and their interactions.

\begin{tabular}{|c|c|c|c|c|c|c|c|c|c|c|}
\hline \multirow[b]{2}{*}{ Tart's } & \multicolumn{6}{|c|}{ Levels } & \multirow{2}{*}{$\begin{array}{l}\text { Oil } \\
(\%)\end{array}$} & \multirow{2}{*}{$\begin{array}{l}\text { Oil yield } \\
\text { (ton/ ha) }\end{array}$} & \multirow{2}{*}{$\begin{array}{c}\text { Starch } \\
(\%)\end{array}$} & \multirow{2}{*}{$\begin{array}{c}\text { Total sugar } \\
(\%)\end{array}$} \\
\hline & I & $\mathbf{K}$ & $\mathbf{P}$ & $\mathbf{N}$ & SD & PD & & & & \\
\hline $\mathrm{C}_{1-12}$ & 0 & 0 & 0 & 0 & 0 & 0 & 6.63 & 0.45 & 63.00 & 6.22 \\
\hline$S_{1}$ & - & 0 & 0 & 0 & 0 & 0 & 7.15 & 0.55 & 61.29 & 4.73 \\
\hline$S_{2}$ & + & 0 & 0 & 0 & 0 & 0 & 6.50 & 0.46 & 62.58 & 6.48 \\
\hline $\mathrm{S}_{3}$ & 0 & - & 0 & 0 & 0 & 0 & 5.88 & 0.40 & 66.26 & 6.22 \\
\hline $\mathrm{S}_{4}$ & 0 & + & 0 & 0 & 0 & 0 & 6.78 & 0.61 & 64.50 & 7.54 \\
\hline $\mathrm{S}_{5}$ & 0 & 0 & - & 0 & 0 & 0 & 6.12 & 0.46 & 64.97 & 7.26 \\
\hline $\mathrm{S}_{6}$ & 0 & 0 & + & 0 & 0 & 0 & 6.76 & 0.65 & 64.22 & 5.59 \\
\hline $\mathrm{S}_{7}$ & 0 & 0 & 0 & - & 0 & 0 & 7.20 & 0.40 & 70.03 & 8.25 \\
\hline $\mathrm{S}_{8}$ & 0 & 0 & 0 & + & 0 & 0 & 6.54 & 0.49 & 64.12 & 7.22 \\
\hline $\mathrm{S}_{9}$ & 0 & 0 & 0 & 0 & - & 0 & 6.50 & 0.40 & 69.00 & 7.80 \\
\hline $\mathrm{S}_{10}$ & 0 & 0 & 0 & 0 & + & 0 & 7.05 & 0.44 & 66.45 & 7.21 \\
\hline $\mathrm{S}_{11}$ & 0 & 0 & 0 & 0 & 0 & - & 7.00 & 0.38 & 65.10 & 7.12 \\
\hline$S_{12}$ & 0 & 0 & 0 & 0 & 0 & + & 7.50 & 0.68 & 63.40 & 6.73 \\
\hline $\mathrm{F}_{1}$ & -1 & -1 & -1 & -1 & -1 & -1 & 6.71 & 0.27 & 65.08 & 7.85 \\
\hline $\mathrm{F}_{2}$ & -1 & -1 & -1 & -1 & 1 & 1 & 7.03 & 0.44 & 68.20 & 7.85 \\
\hline $\mathrm{F}_{3}$ & -1 & -1 & -1 & 1 & -1 & 1 & 6.75 & 0.36 & 73.00 & 7.55 \\
\hline $\mathrm{F}_{4}$ & -1 & -1 & -1 & 1 & 1 & -1 & 6.52 & 0.31 & 74.15 & 7.26 \\
\hline $\mathrm{F}_{5}$ & -1 & -1 & 1 & -1 & -1 & 1 & 6.80 & 0.47 & 70.25 & 8.06 \\
\hline $\mathrm{F}_{6}$ & -1 & -1 & 1 & -1 & 1 & -1 & 6.74 & 0.34 & 73.40 & 7.36 \\
\hline $\mathrm{F}_{7}$ & -1 & -1 & 1 & 1 & -1 & -1 & 6.53 & 0.28 & 75.61 & 7.00 \\
\hline $\mathrm{F}_{8}$ & -1 & -1 & 1 & 1 & 1 & 1 & 6.60 & 0.37 & 72.79 & 6.50 \\
\hline $\mathrm{F}_{9}$ & -1 & 1 & -1 & -1 & -1 & 1 & 6.22 & 0.37 & 73.10 & 7.84 \\
\hline $\mathrm{F}_{10}$ & -1 & 1 & -1 & -1 & 1 & -1 & 7.03 & 0.32 & 70.25 & 7.75 \\
\hline $\mathrm{F}_{11}$ & -1 & 1 & -1 & 1 & -1 & -1 & 7.21 & 0.55 & 74.80 & 8.85 \\
\hline $\mathrm{F}_{12}$ & -1 & 1 & -1 & 1 & 1 & 1 & 7.14 & 0.51 & 69.05 & 9.27 \\
\hline $\mathrm{F}_{13}$ & -1 & 1 & 1 & -1 & -1 & -1 & 6.55 & 0.53 & 64.25 & 8.34 \\
\hline $\mathrm{F}_{14}$ & -1 & 1 & 1 & -1 & 1 & 1 & 6.91 & 0.52 & 64.58 & 7.61 \\
\hline $\mathrm{F}_{15}$ & -1 & 1 & 1 & 1 & -1 & 1 & 6.54 & 0.36 & 67.15 & 6.55 \\
\hline $\mathrm{F}_{16}$ & -1 & 1 & 1 & 1 & 1 & -1 & 7.12 & 0.35 & 70.06 & 7.27 \\
\hline $\mathrm{F}_{17}$ & 1 & -1 & -1 & -1 & -1 & 1 & 6.76 & 0.33 & 65.45 & 8.06 \\
\hline $\mathrm{F}_{18}$ & 1 & -1 & -1 & -1 & 1 & -1 & 6.56 & 0.42 & 66.15 & 7.68 \\
\hline $\mathrm{F}_{19}$ & 1 & -1 & -1 & 1 & -1 & -1 & 6.00 & 0.40 & 67.95 & 7.03 \\
\hline $\mathrm{F}_{20}$ & 1 & -1 & -1 & 1 & 1 & 1 & 6.56 & 0.51 & 70.16 & 9.02 \\
\hline $\mathrm{F}_{21}$ & 1 & -1 & 1 & -1 & -1 & -1 & 6.74 & 0.40 & 66.15 & 8.59 \\
\hline $\mathrm{F}_{22}$ & 1 & -1 & 1 & -1 & 1 & 1 & 6.21 & 0.43 & 64.30 & 7.81 \\
\hline $\mathrm{F}_{23}$ & 1 & -1 & 1 & 1 & -1 & 1 & 6.10 & 0.33 & 63.65 & 6.68 \\
\hline $\mathrm{F}_{24}$ & 1 & -1 & 1 & 1 & 1 & -1 & 6.81 & 0.52 & 65.08 & 8.54 \\
\hline $\mathrm{F}_{25}$ & 1 & 1 & -1 & -1 & -1 & -1 & 6.11 & 0.21 & 67.35 & 9.29 \\
\hline $\mathrm{F}_{26}$ & 1 & 1 & -1 & -1 & 1 & 1 & 6.54 & 0.34 & 70.15 & 8.25 \\
\hline $\mathrm{F}_{27}$ & 1 & 1 & -1 & 1 & -1 & 1 & 6.67 & 0.54 & 68.25 & 9.10 \\
\hline $\mathrm{F}_{28}$ & 1 & 1 & -1 & 1 & 1 & -1 & 6.41 & 0.39 & 72.50 & 8.42 \\
\hline $\mathrm{F}_{29}$ & 1 & 1 & 1 & -1 & -1 & 1 & 6.74 & 0.48 & 80.26 & 7.83 \\
\hline $\mathrm{F}_{30}$ & 1 & 1 & 1 & -1 & 1 & -1 & 6.31 & 0.36 & 68.25 & 8.43 \\
\hline $\mathrm{F}_{31}$ & 1 & 1 & 1 & 1 & -1 & -1 & 6.53 & 0.29 & 70.08 & 7.78 \\
\hline $\mathrm{F}_{32}$ & 1 & 1 & 1 & 1 & 1 & 1 & 7.02 & 0.45 & 68.72 & 8.17 \\
\hline
\end{tabular}




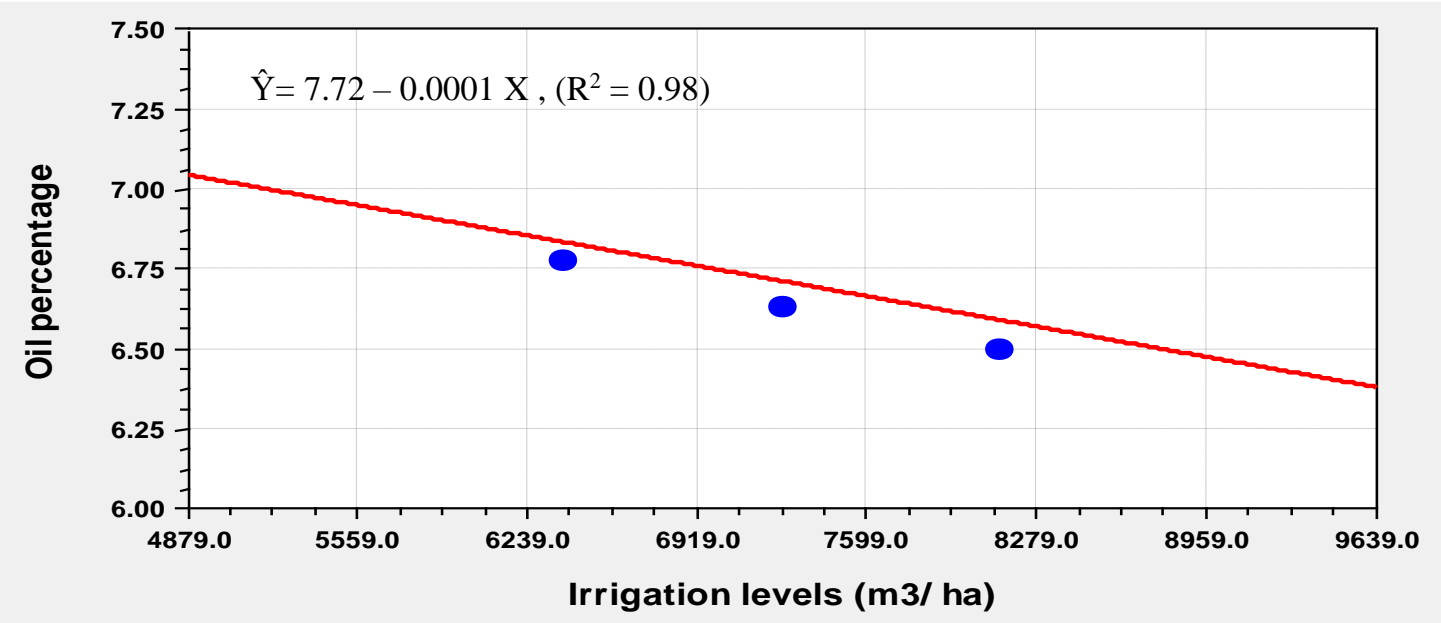

Fig. 1. Effect of irrigation levels on oil percentage

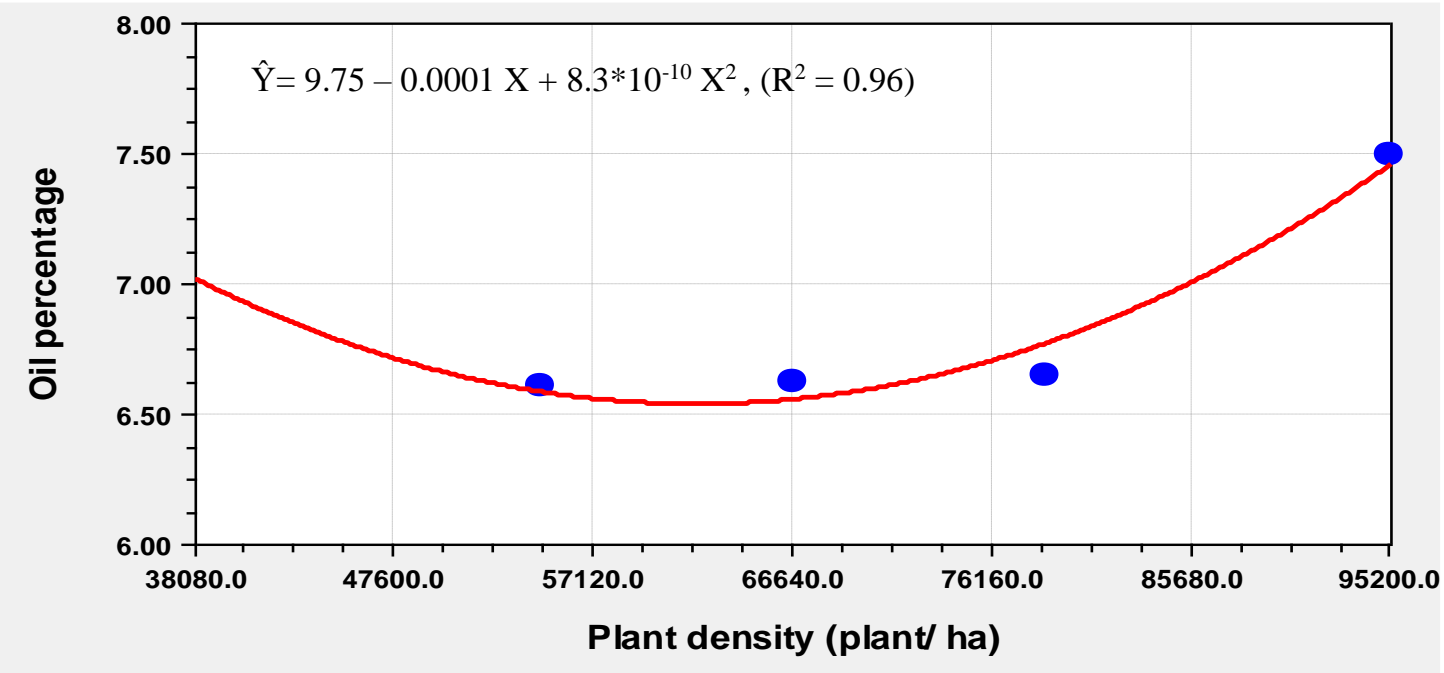

Fig. 2. Effect of plant density on oil percentage
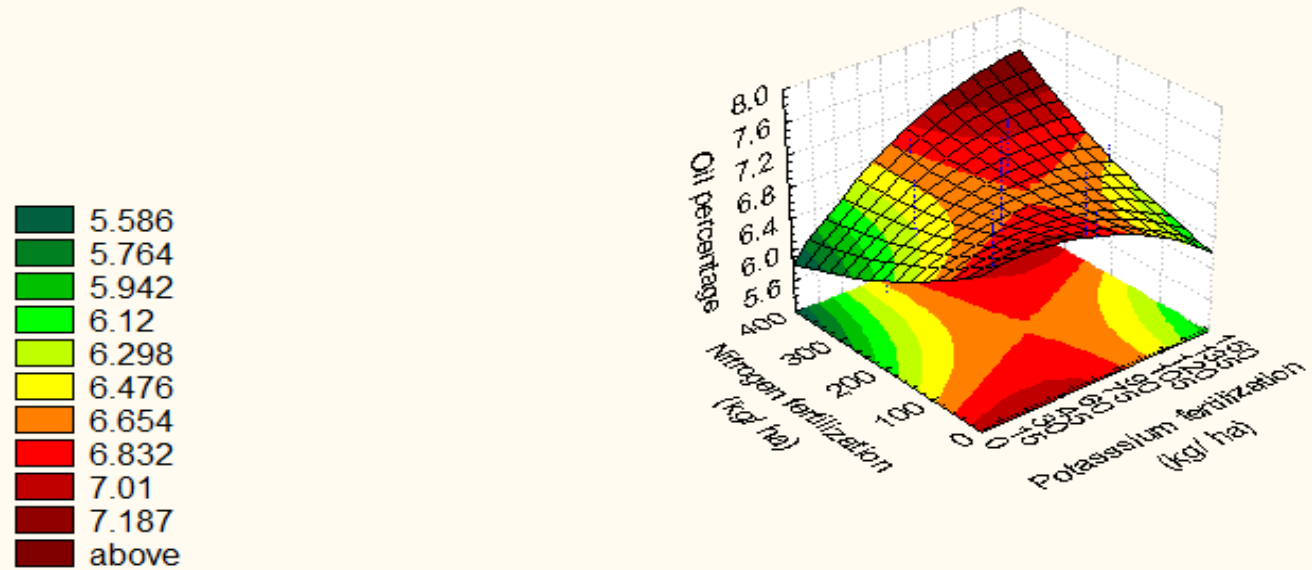

Fig. 3. Response surface for oil percentage as affected by potassium and nitrogen fertilization interaction at the central levels of irrigation levels, phosphorus fertilization, sowing date and plant density 


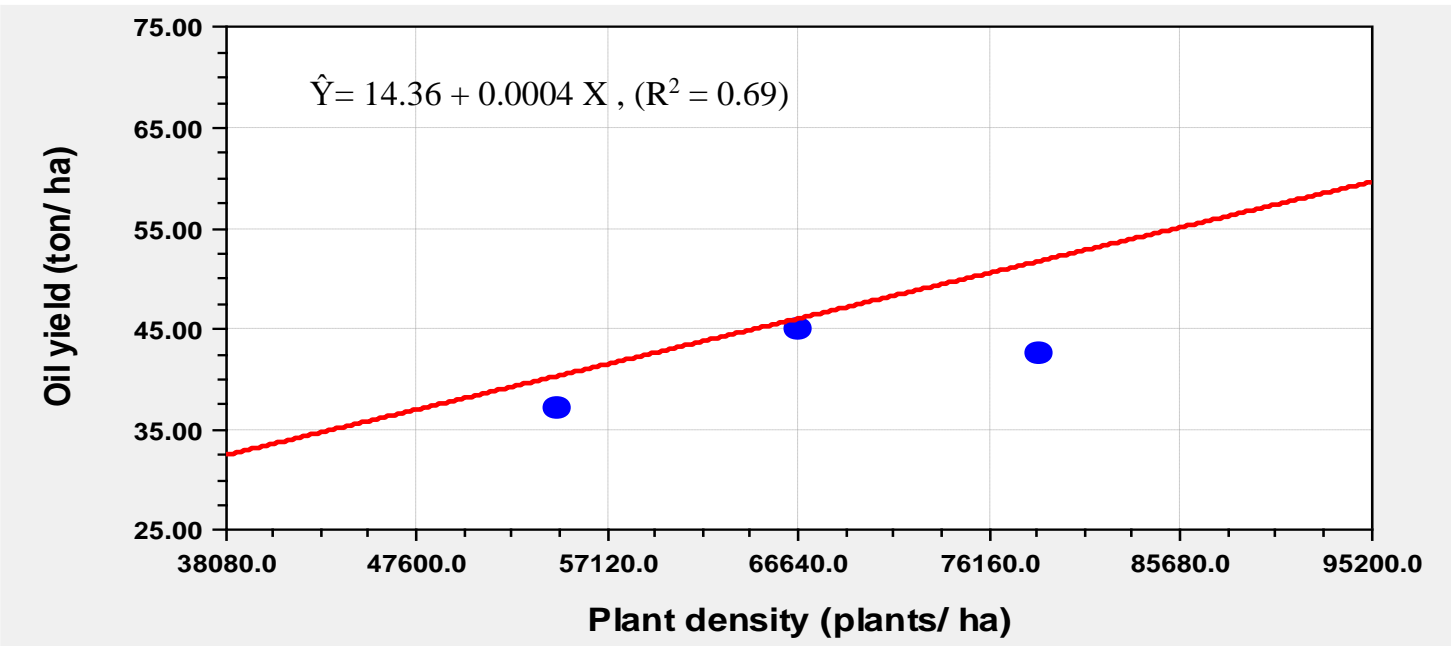

Fig. 4. Effect of plant density on oil yield

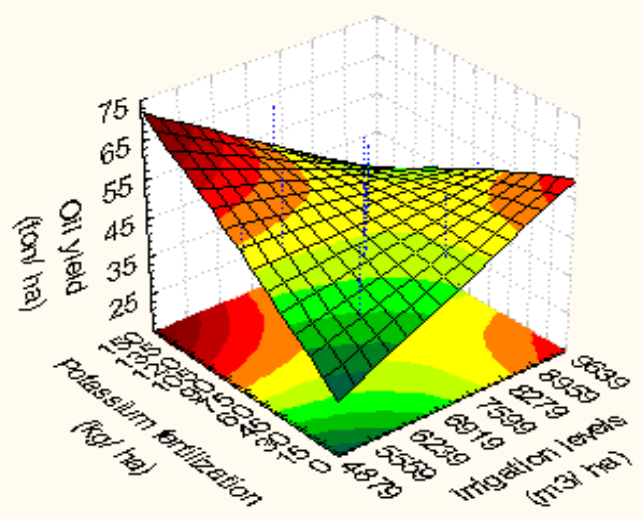

Fig. 5. Response surface for oil yield as affected by irrigation levels and potassium fertilization interaction at the central levels of phosphorus, nitrogen fertilization, sowing date and plant density

13.44

18.854

24.267

29.681

35.095

40.508

45.922

51.335

56.749

62.163

above

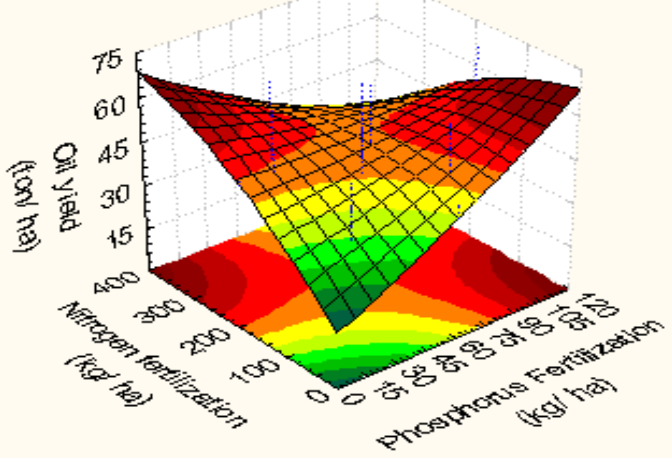

Fig. 6. Response surface for oil yield as affected by phosphorus and nitrogen fertilization interaction at the central levels of irrigation levels, potassium fertilization, sowing date and plant density 

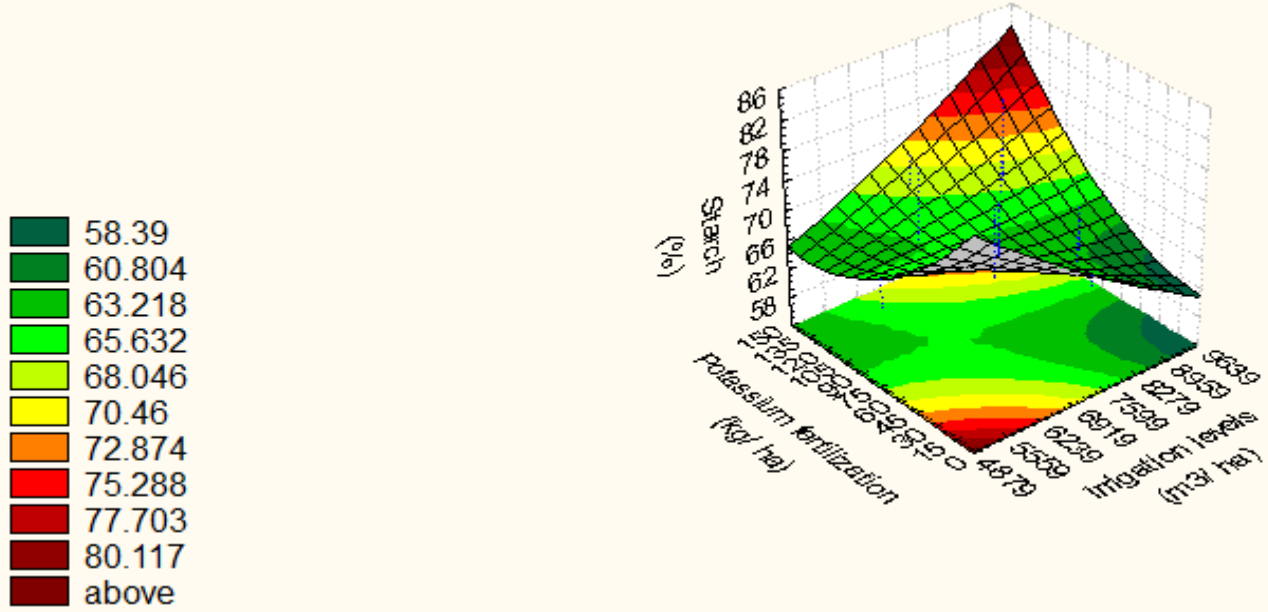

Fig. 7. Response surface for starch percentage as affected by irrigation levels and potassium fertilization interaction at the central levels of phosphorus, nitrogen fertilization, sowing date and plant density
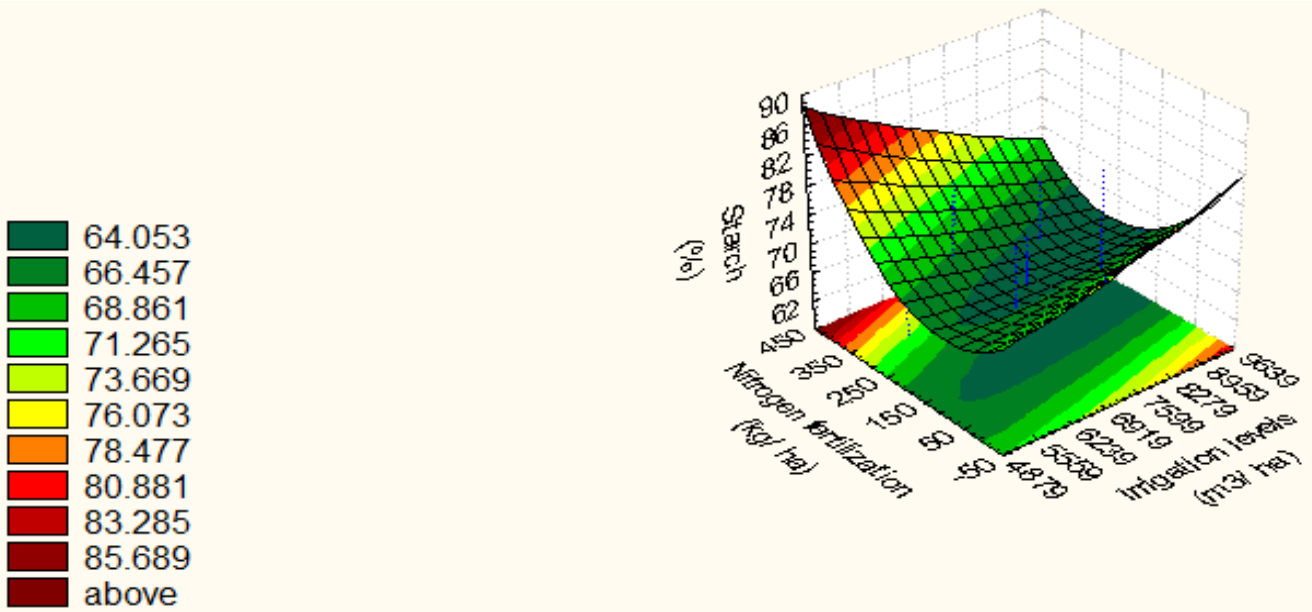

Fig. 8. Response surface for starch percentage as affected by irrigation levels and nitrogen fertilization interaction at the central levels of potassium, phosphorus fertilization, sowing date and plant density
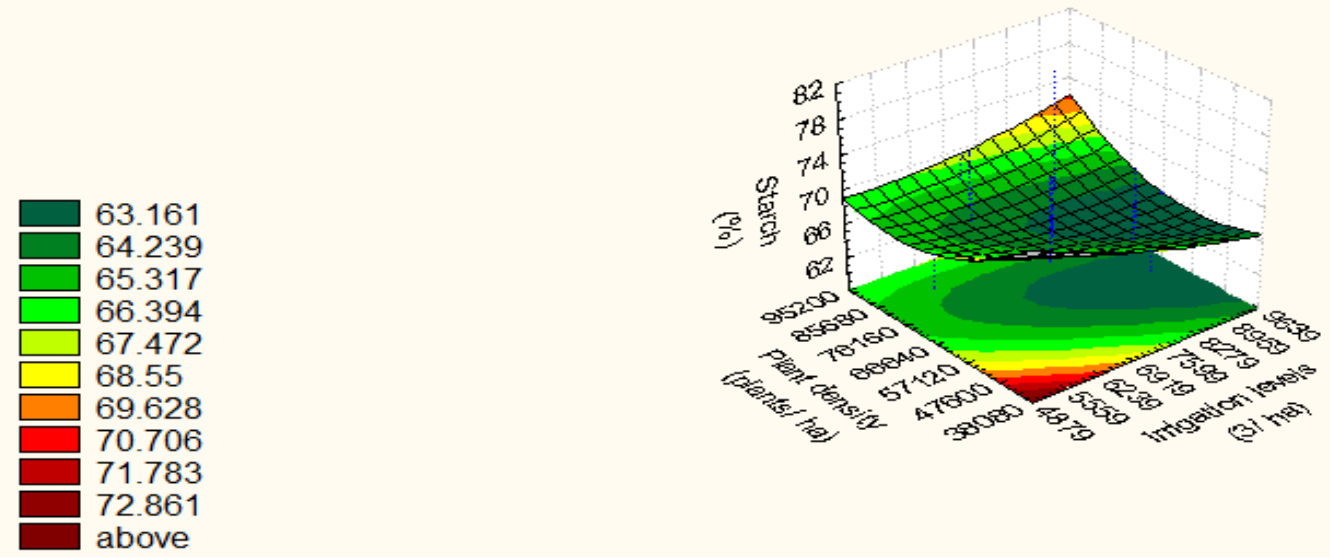

Fig. 9. Response surface for starch percentage as affected by irrigation levels and plant density interaction at the central levels of potassium, phosphorus, nitrogen fertilization and sowing date 

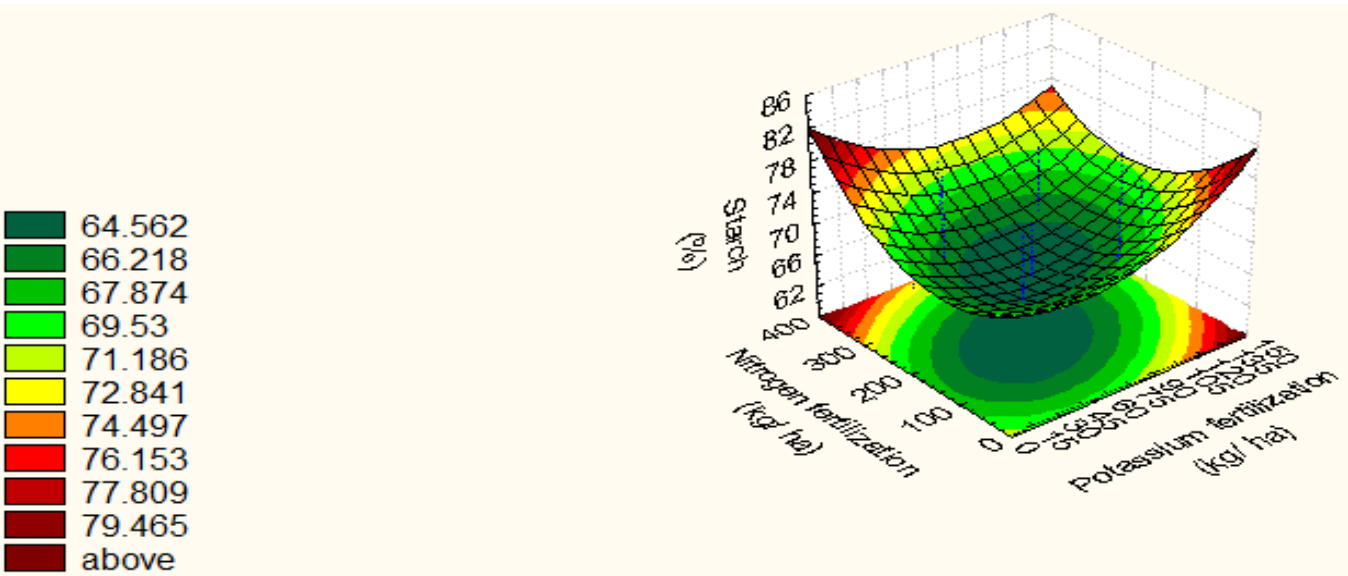

Fig. 10. Response surface for starch percentage as affected by potassium and nitrogen fertilization at the central levels of irrigation levels, phosphorus fertilization, sowing date and plant density
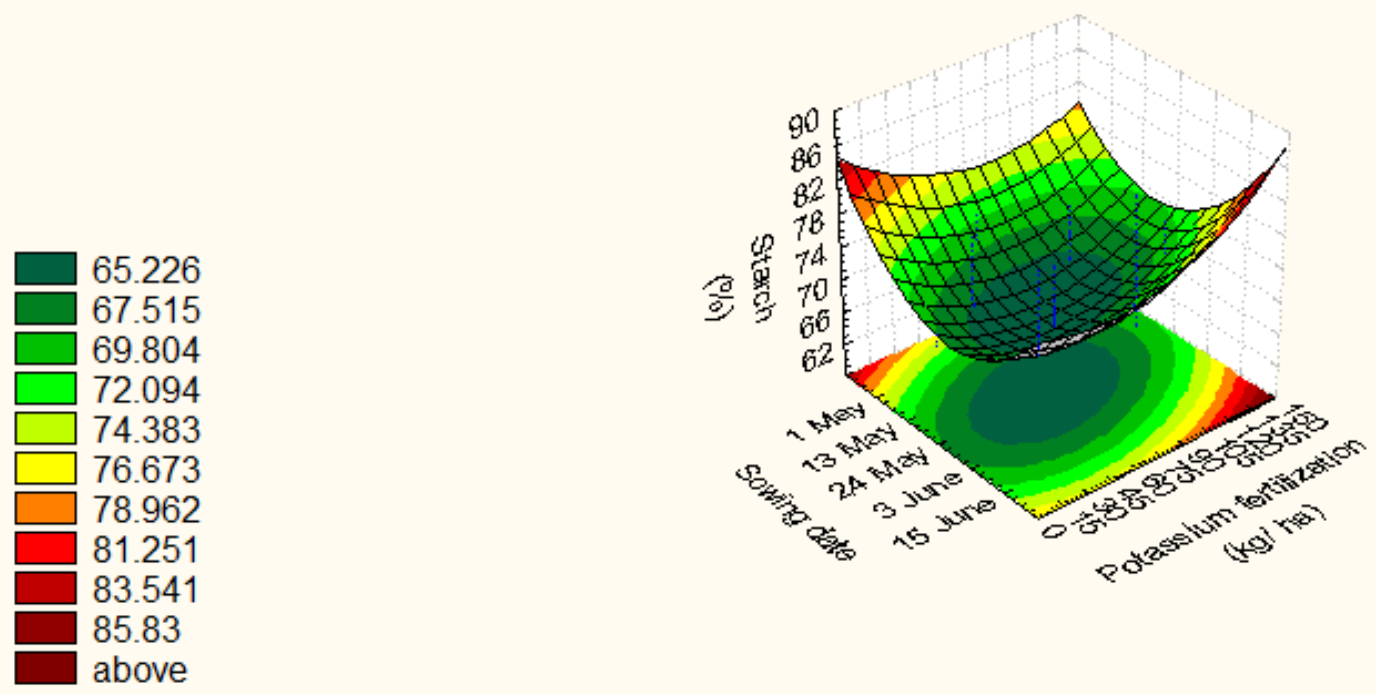

Fig. 11. Response surface for starch percentage as affected by potassium fertilization and sowing date interaction at the central levels of irrigation levels, phosphorus, nitrogen fertilization, sowing date and plant density

64.695

66.431

68.167

69.903

71.638

73.374

75.11

76.846

78.581

80.317

above

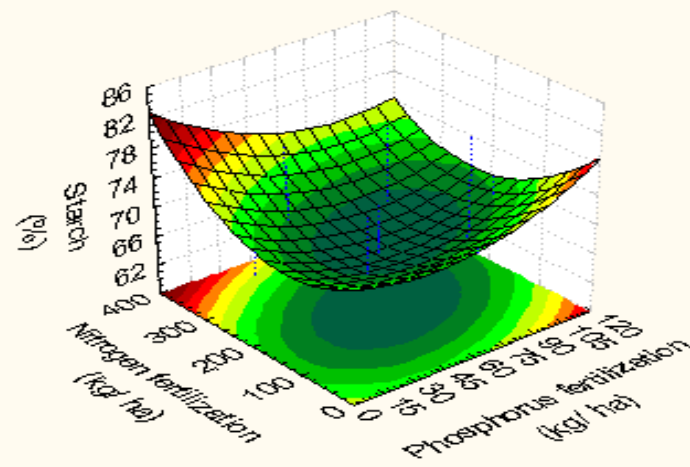

Fig. 12. Response surface for starch percentage as affected by phosphorus and nitrogen fertilization interaction at the central levels of irrigation levels, potassium fertilization, sowing date and plant density 

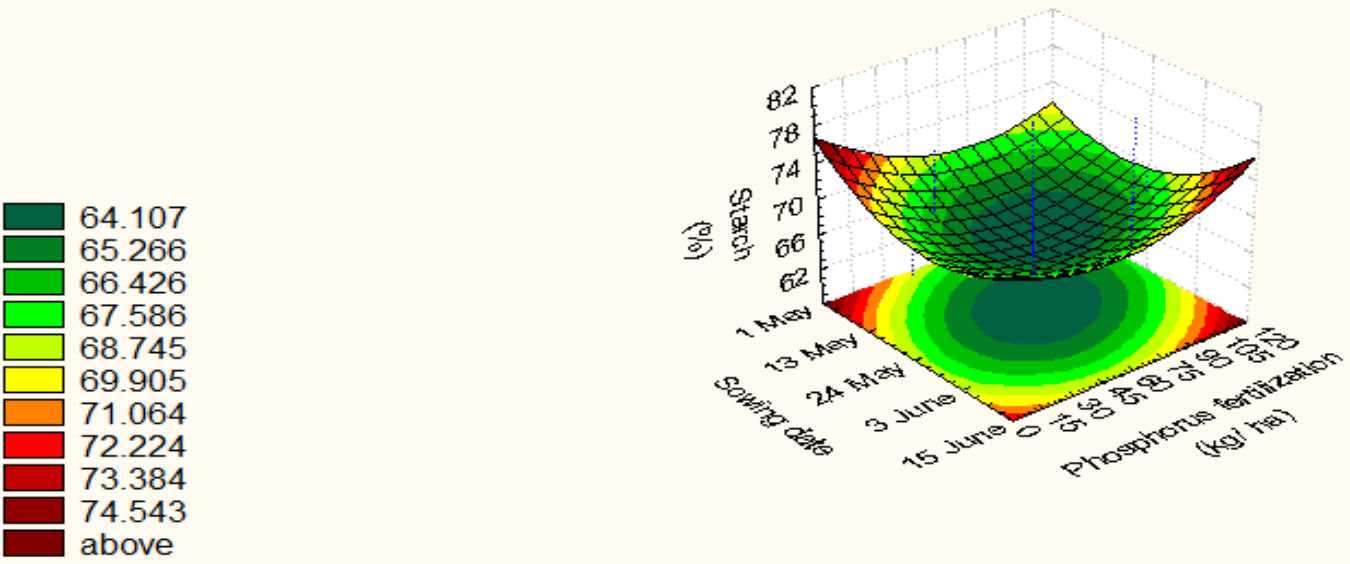

Fig. 13. Response surface for starch percentage as affected by phosphorus fertilization and sowing date interaction at the central levels of irrigation levels, potassium, nitrogen fertilization and plant density
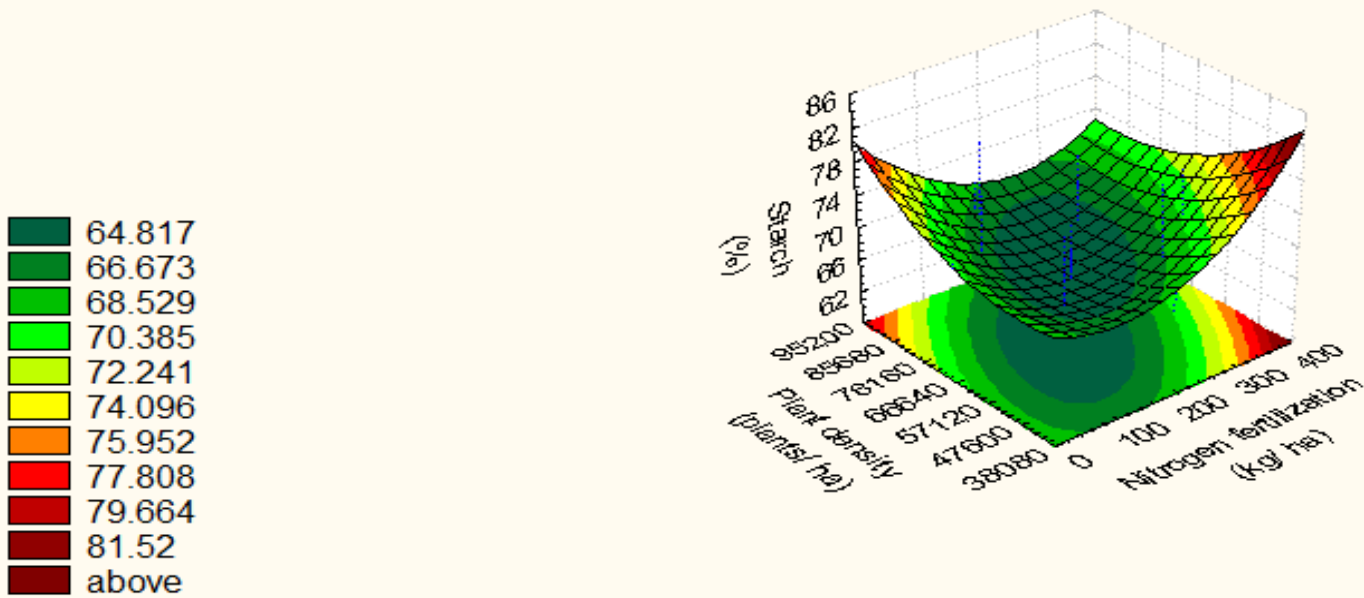

Fig. 14. Response surface for starch percentage as affected by nitrogen fertilization and plant density interaction at the central levels of irrigation levels, potassium, phosphorus fertilization and sowing date
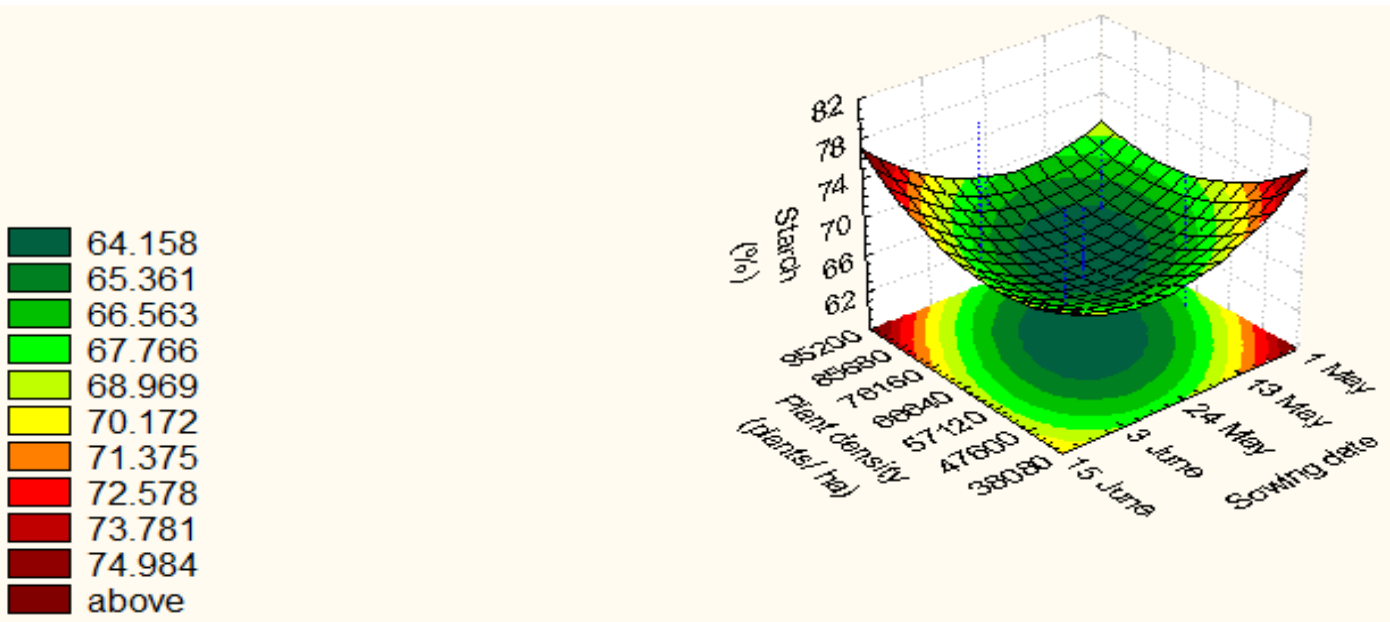

Fig. 15. Response surface for starch percentage as affected by sowing date and plant density interaction at the central levels of irrigation levels, potassium, phosphorus and nitrogen fertilization 
Application of higher levels of nitrogen fertilization increase grain starch content due to the role of $\mathrm{N}$ in increasing photosynthetic area and photoassimilates production. Potassium has a major role in translocation of photoassimilates to the grains especially at low $\mathrm{N}$ availability. Similarly, $\mathrm{P}$ enhances starch synthesis through its role in energy storage and metabolism of carbohydrates and enhancement of $\mathrm{N}$ uptake by plants. Irrigation is essential for nutrients uptake by plants and translocation of assimilates to grains, hence, availability of water during grain formation and filling stages is essential for increasing grain starch content. Early sowing, especially at low plant density and availability of growth resources, enhances maize plants to perform the bioprocesses under favorable conditions leading to proper grain filling and increase in starch content compared to late sowings. These findings are in accordance with those reported by Ibrahim and Kandil 2007, Bukhsh et al., 2009, Ahouelete et al., 2011, Ali et al., 2013, Koca and Canavar, 2014, Kaur and Kumar 2017 and Abhishek and Basavanneppa, 2020.

The coefficient of variation for grain starch content was $1.7 \%$ (Table 3) indicating that this character depended mainly on the variation of factor levels, and their different interactions.

These findings were confirmed by the means of grain starch content for interaction, where the highest values were obtained at the high levels of irrigation, potassium, phosphorus fertilization and plant density early sowing date in addition to low nitrogen compared to the other lower levels of the studied factors as indicated in (Table 4).

\section{4- Grain total sugar content:}

The regression coefficient values (Table 3) showed that the grain total sugar content was significantly and positively affected by the linear component for irrigation levels $\left(0.275^{*}\right)$ and negatively affected by the linear component for phosphorus fertilization levels ($\left.0.289^{*}\right)$. The quadratic component for potassium and the nitrogen fertilization levels, sowing date and plant density positively affected grain total sugar content $\left(0.253^{*}, 0.405^{*}, 0.364^{*}\right.$ and $0.261^{*}$, respectively). Hence, the regression equation that explain the relationship between grain total sugar content and significant components will be

$\mathrm{Y}=6.181+0.275 \mathrm{X}_{1}+0.253 \mathrm{X}_{2}^{2}-0.289 \mathrm{X}_{3}+0.405 \mathrm{X}_{4}^{2}$ $+0.364 X_{5}^{2}+0.261 X_{6}^{2}$

The regression analysis on irrigation levels (fig.16) showed that the grain total sugar content was increased linearly with increasing levels of irrigation with $\mathrm{R}^{2}=$ 0.22 .
Moreover, the quadratic relationship for potassium fertilization with grain total sugar content (fig.17), indicated an increase in that character with increasing potassium fertilization levels with $\mathrm{R}^{2}=0.34$. The optimal level for potassium fertilization was predicted to be $136.2 \mathrm{~kg} \mathrm{~K}_{2} \mathrm{O} /$ ha.

The relationship between grain total sugar content and phosphorus fertilization (fig.18) showed a significant and negative linear decrease with increasing phosphorus fertilization levels $\left(\mathrm{R}^{2}=0.34\right)$.

Concerning nitrogen fertilization (fig. 19), the regression line showed that the grain total sugar content decreased with increasing nitrogen fertilization levels up to $250 \mathrm{~kg} \mathrm{~N} / \mathrm{ha}$, then increased. The quadratic relationship had an $\mathrm{R}^{2}$ value of 0.32 . The optimal nitrogen fertilization was $258 \mathrm{~kg} \mathrm{~N} / \mathrm{ha}$.

With regard to sowing date (fig.20), the quadratic relationship was positive where grain total sugar content decreased with delaying sowing up to 25 May, then increased $\left(\mathrm{R}^{2}=0.16\right)$. The optimal sowing date was 19 May.

On the other hand, the regression of grain total sugars content on plant density (fig.21), showed a positive quadratic relationship with grain total sugars content. That character increased with increasing plant density up to $66640 \mathrm{plant} / \mathrm{ha}$, then decreased. The relationship had $\mathrm{R}^{2}$ value of 0.06 . The optimal plant density was 56859 plants/ ha.

The coefficient of variation for grain total sugar content was $11.0 \%$ (Table3), which is a relatively high value that indicates the involvement of other factors, than those under study, in determining the expression of that character in maize grains. That was also observed with the relatively low $\mathrm{R}^{2}$ value (0.69) of the regression equation.

These findings were confirmed by the mean grain total sugar content, as indicated in Table 4 where the highest value $(9.29 \%)$ was obtained at the high level of irrigation and potassium fertilization, low levels of phosphorus and nitrogen fertilization, early sowing date and low plant density $\left(\mathrm{F}_{25}\right)$.

Means presented in table (4) revealed higher values of grain total sugar content, on average, at higher levels of irrigation, $\mathrm{N}$ and $\mathrm{K}$ fertilization levels. That may be attributed to the role of those three factors in enhancing photoassimilates production, especially starch and their translocation to the grains. Ali et al. (2013) and Liu et al. (2013) found that maize plants subjected to different degrees of drought led to a significant decrease in grain sugar content. Abhishek and Basavanneppa (2020) also reported that increasing $\mathrm{N}$ fertilization levels resulted in an increase in grain total sugar content. Moreover, it 
was observed that late sowing and higher plant densities showed relatively higher values for that character. That contradicts with Kara et al. (2012) and Abhishek and Basavanneppa (2020), who reported that high plant density and deviation from optimal sowing date of maize decreases grain sugars content.
In this study, higher plant density and late sowing resulted in smaller grains (Zakaria 2017), hence lower starch content and an apparent increase in other components of the grain such as oil and sugar contents. The negative relationship between $\mathrm{P}$ fertilization levels and that character may be due to the role of $\mathrm{P}$ in increasing fatty components of the grain, thus decreasing other components including sugar content.

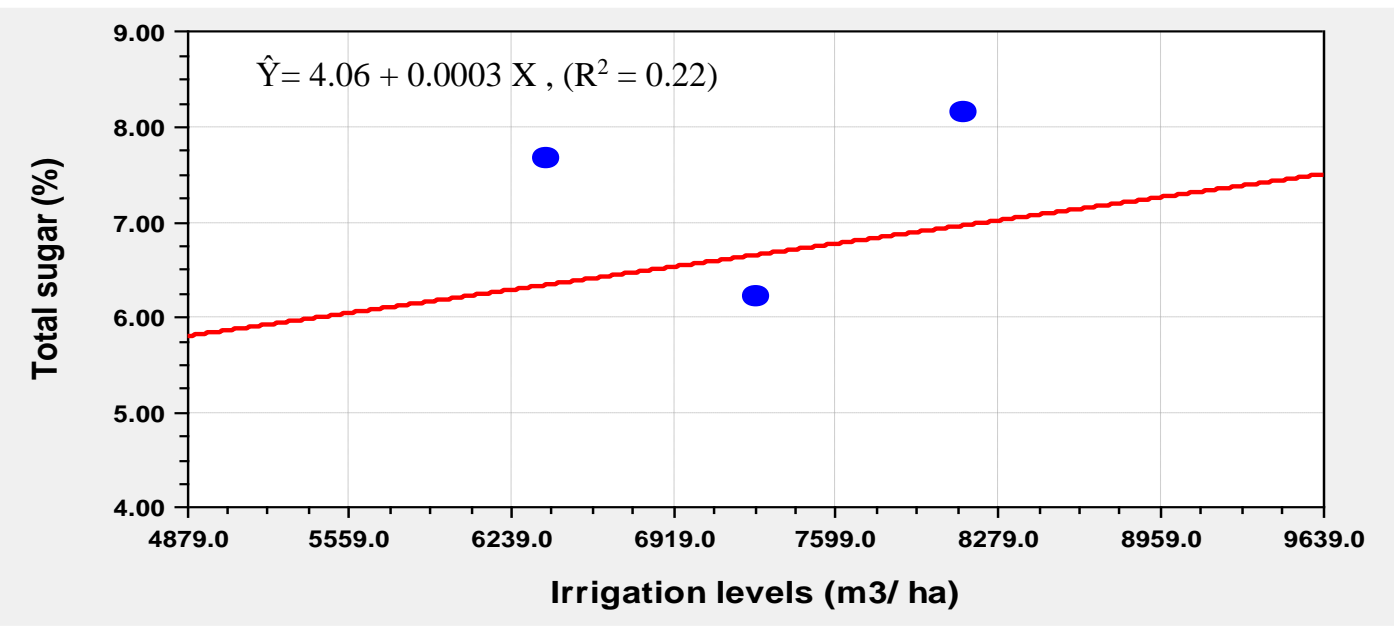

Fig. 16. Effect of irrigation levels on total sugar percentage

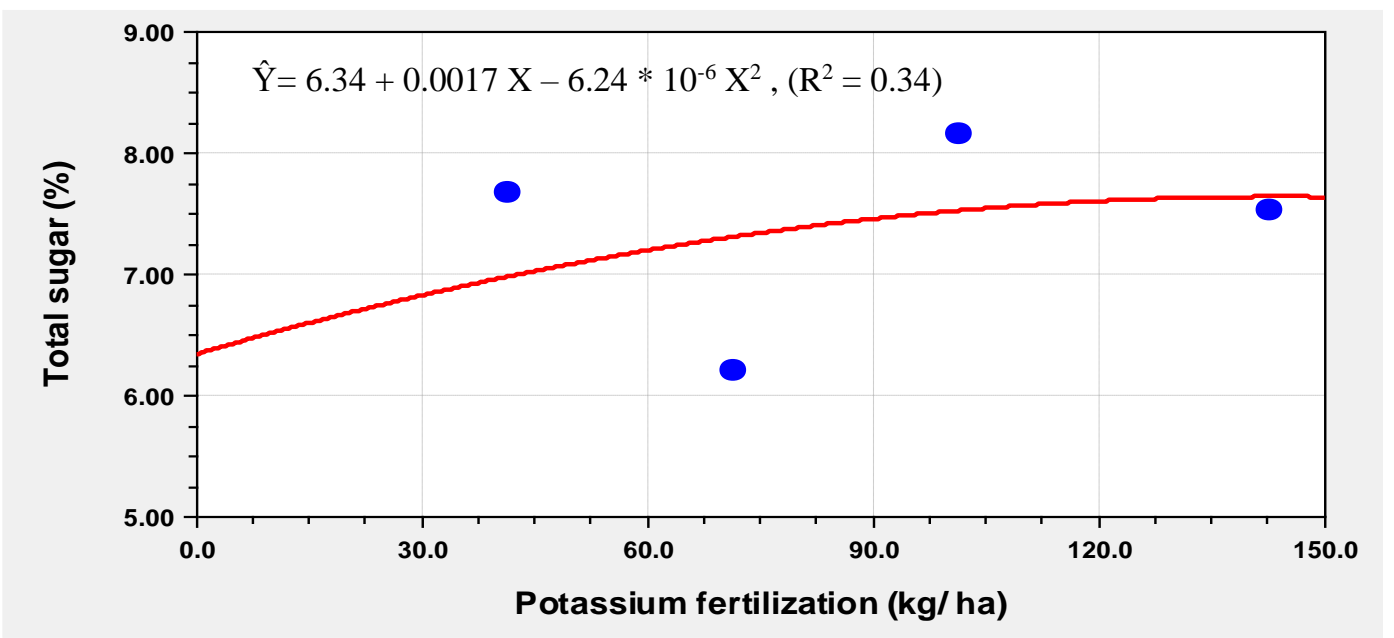

Fig. 17. Effect of potassium fertilization on total sugar percentage 


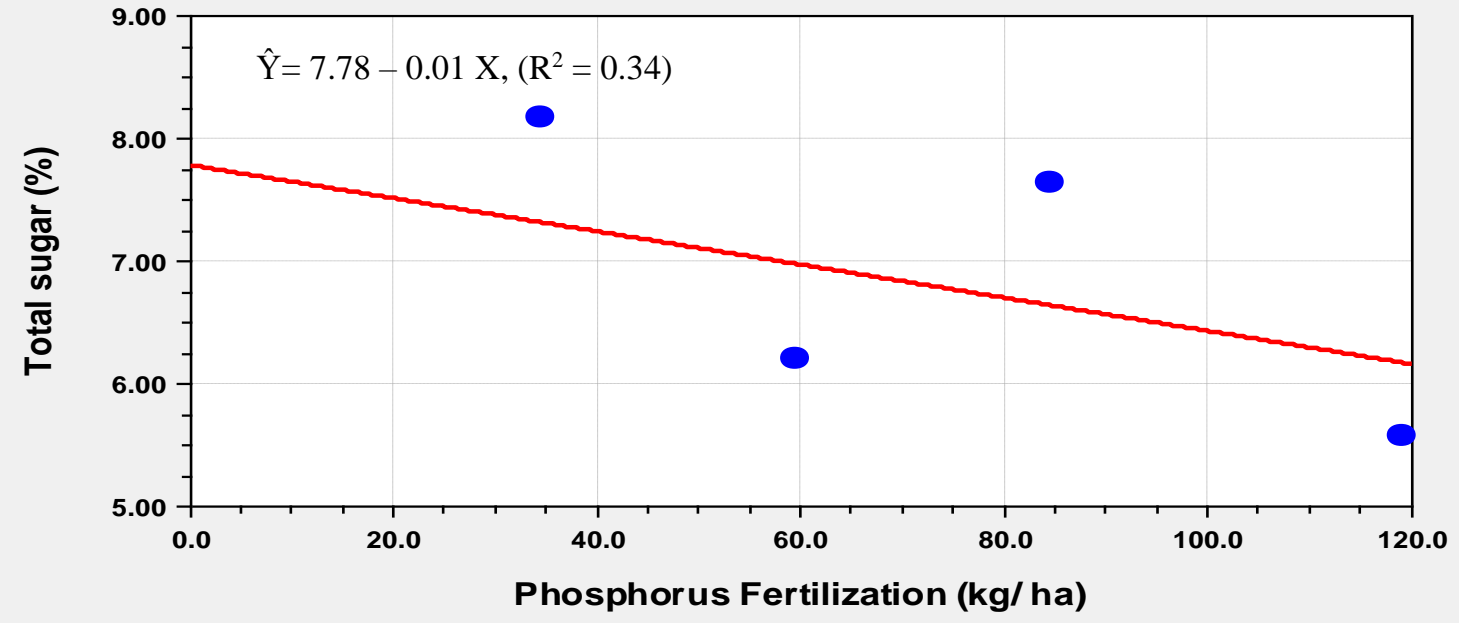

Fig. 18: Effect of phosphorus fertilization on total sugar percentage

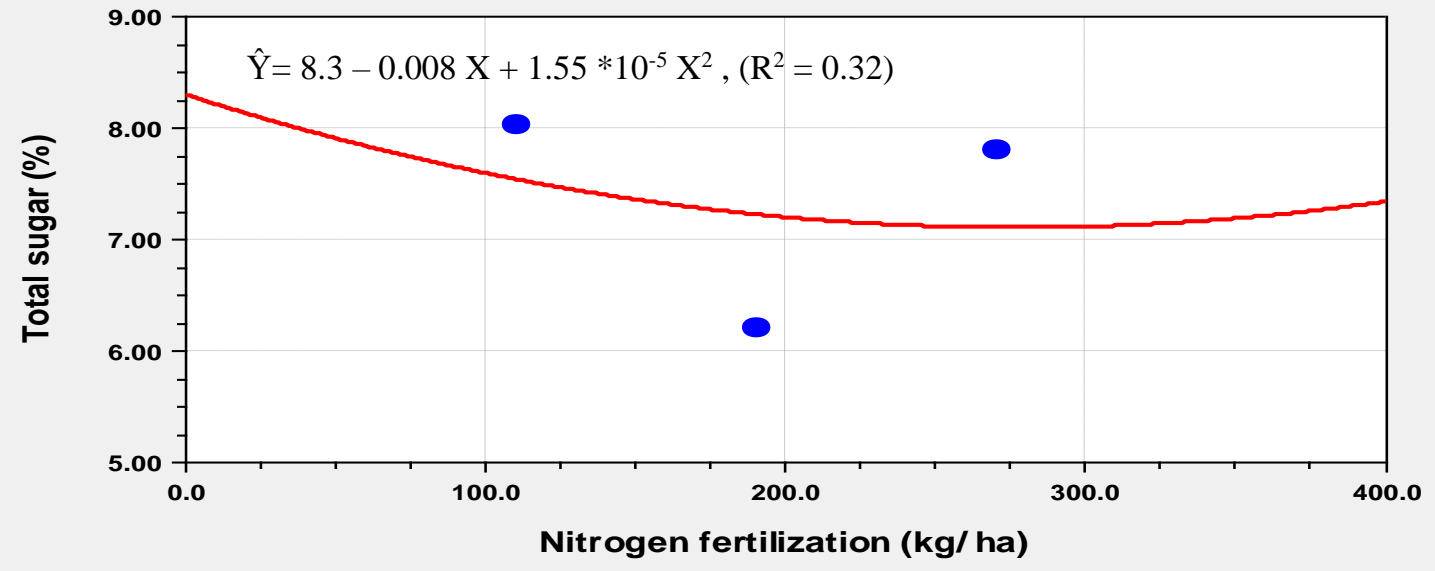

Fig. 19: Effect of nitrogen fertilization on total sugar percentage

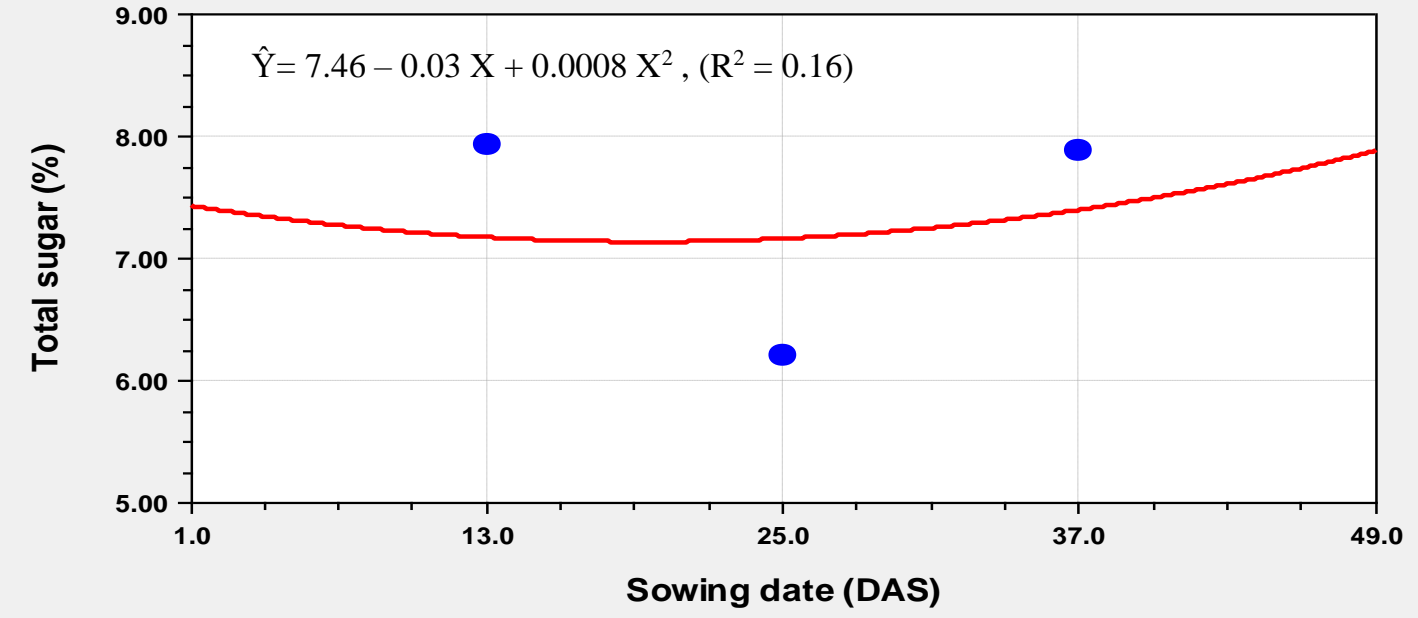

Fig. 20: Effect of sowing date on total sugar percentage 


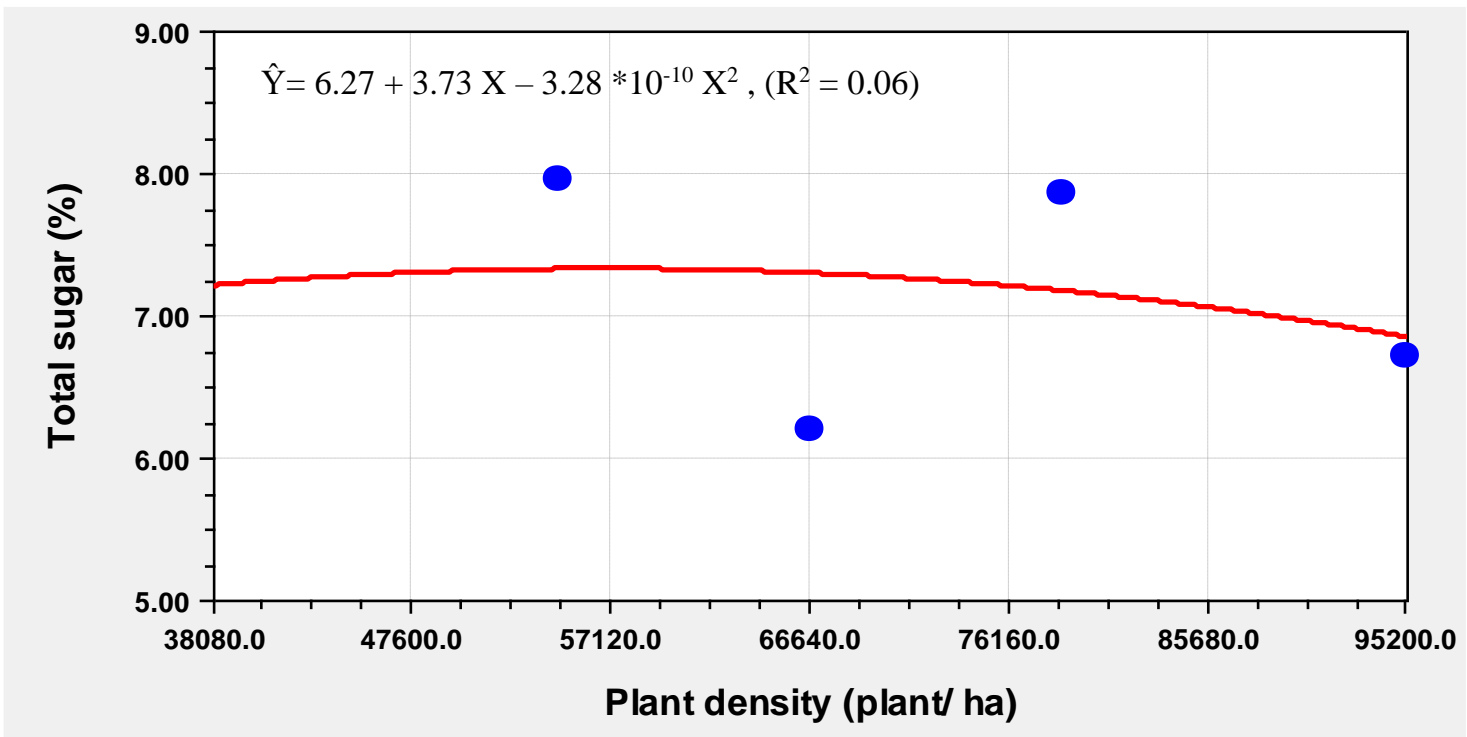

Fig. 21. Effect of plant density on total sugar percentage

\section{CONCLUSION}

It be concluded that maize grain quality characters may be improved with application of appropriate levels of the studied factors. Early sowing in May (20-30 May) and 60,000 plants/ ha are recommended for high oil and starch contents. Low irrigation level, on the other hand, showed an apparent increase in oil content due to a considerable decrease in starch content. Fertilization with the major macronutrients $(\mathrm{N}, \mathrm{P}$ and $\mathrm{K})$ affected grain quality characters, where levels of $136 \mathrm{~kg} \mathrm{~K}_{2} \mathrm{O}$ / ha and $258 \mathrm{~kg} \mathrm{~N} / \mathrm{ha}$ improved oil and starch contents in addition to total sugars. On the other hand, increasing $\mathrm{P}$ levels above $50 \mathrm{~kg} \mathrm{P}_{2} \mathrm{O}_{5} /$ ha decreased total sugars.

\section{REFERENCES}

A.O.A.C. 1990. Official Methods of Analysis of the Association of Official Agricultural Chemists. 12nd. Edition, Washington, D.C.

Abhishek, N. and M.A. Basavanneppa. 2020. Effect of plant densities and nitrogen levels on cob yield and quality parameters of sweet corn (zea mays L.) Saccharata in irrigation ecosystem. IJCS. 8 (2): 1918-1921.

Ahouelete, R., Y. Holou and V. Kindomihou. 2011. Impact of nitrogen fertilization on the oil, protein, starch and ethanol yield of corn (zea mays L.) grown for biofuel production. J. Life Sci. 5: 1013- 1021.

Ali, Q., F. Anwar, M. Ashraf, N. Saari and R. Perveen. 2013. Ameliorating effects of exogenously applied proline on seed composition, seed oil quality and oil antioxidant activity of maize (zea mays L.) under drought stress. Int. J. Mol. Sci. 14: 818- 835.
Ayub, M., M.A. Nadeem, M.S. Sharar and N. Mahmood. 2002. Response of maize (Zea mays L.) fodder to different levels of nitrogen and phosphorus. Asian J. Pl. Sci. 1: 352354.

Black, C.A., D. D. Evans, J. L.White, L.E. Ensminger and F. E. Clark. 1965. Methods of soil analysis. Part1 physical and mineralogical properties.Including statistics of measurement and sampling. American. Society of Agronomy. Inc., Publisher Madison. Wiscons. U.S.A.

Box, G.E.P. and K.B. Wilson. 1951. On the experimental attainment of optimum conditions. J.R. Stat. Soc. B. 13:145.

Bukhsh, M.A., R. Ahmad, M. Lshaque and A.U. Malik. 2009. Response of maize hybrids to varying potassium application in Pakistan. Pak. J. Agric. Sci. 46 (3): 179184.

Cochran, W.G. and G.M. Cox. 1957. Experimental Designs. John Wiley \&Sons, INC.N.Y. USA.

Comeroglu, B. 1992. Basic Analysis Principle in Fruit and Vegetative Processing Industry. Biltav Press Ankara. p. 381.

Fageria, N.K. and M.P. Barbosafilho. 2007. Dry matter and grain yield, nutrient uptake, and phosphorus efficiency of upland rice as influenced by phosphorus fertilization. Commun. Soil Sci., Plant Anal. 38: 1289- 1297.

Ghassemi-Golezani, K., N. Raei and Y. Rae. 2015. Effects of water deficit and nitrogen levels on grain yield and oil and protein contents of maize. Azarian J. Agric. 2: 46-50.

Hartley, H.O. 1950. The Maximum F-ratio as a Short-cut Test for Heterogeneity of Variance. Biometrika. 37: 3/4: 308312.

Hyams, D. 2005. Curve Expert Version 1.37. A comprehensive curve fitting package for Windows. 
Ibrahim, S.A. and H. Kandil. 2007. Growth, yield and chemical constituents of corn (zea mays L.) as affected by nitrogen and phosphorus fertilization under different irrigation intervals. J. Appl. Sci. Res. 3 (10): 1112- 1120.

Kaplan, M., H. Kale, K. Karaman and A. Unlukara. 2017. Influence of different irrigation and nitrogen levels on crude oil and fatty acid composition of maize (zea mays L.). Grasas Aceites 68 (3). July- September,e07.ISSNL:0017-3495 doi:http://dx.doi.org/10.3989/gya.0222171.

Kara, B., B. Atar and H. Gul. 2012. Effects of different sowing dates on protein, sugar and dry matter of sweet corn. Res on Crops. 13 (2): 493- 497.

Karasu, A., H. Kuşcu, M. Öz and G. Bayram. 2015. The effect of different irrigation water levels on grain yield, yield components and some quality parameters of silage maize (Zea mays L.) indentate sturt. in Marmara Region of Turkey. Not Bot. Hort. Agrobo. 43(1):138-145. Available online: www.notulaebdonicae.ro

Kaur, A. and M. Kumar. 2017. Effect of different planting methods and nitrogen levels on the quality of Kharif maize (zea mays L.). Adv. Res. J. Impra. 8 (2): 179- 182.
Koca, Y.O. and O. Canavar. 2014. The effect of sowing date on yield and yield components and seed quality of corn (Zea mays L.). Series A. Agron. LVII: 227-231.

Liu, L., N. Klocke, S. Yan, D. Rogers, A. Schlegel, F. Lamm, S.I. Chang and D. Wang. 2013. Impact of deficit irrigation on maize physical and chemical properties and ethanol yield. Cereal Chem. 90 (5): 453-462.

Malik, C.P. and M.B. Singh. 1980. Plant Enzymology and Histoenzymology. A text Manual-kalyani Publishers. New Delhi. India.

Page, A.L., Miller, R.H. and D.R. Keeney. 1982. Methods of Soil Analysis. Part (2). Agronomy No. 9 Madison. U.S.A.

Peterson, G.R. 1985. Design and Analysis of Experiments. Marcel Dekker, Inc. New York. pp. 253-301.

StatSoft, I. 2012. STATISTICA (data analysis software system). version 7. 2004. Tulsa. USA. 150.

Zakaria, Ola, E. 2017. Optimization of main productivity inputs of maize cv. Giza 168. MSc. Thesis Fac. of Agric., Alex. Univ. Egypt.

$$
\begin{aligned}
& \text { الملخص العربي } \\
& \text { تاثير مستويات الرى وموعد الزراعة والكثافة النباتية وكذلك المغذيات الكبرى على جودة حبوب صنف الذرة }
\end{aligned}
$$

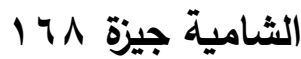

$$
\begin{aligned}
& \text { علا عزت زكريا, محمد ممدوح الروبى, منى محمد حميد }
\end{aligned}
$$

